\title{
Quito's coronavirus curfew: Escalating tropospheric ozone pollution
}

\author{
Cristian Salazar ${ }^{1 *}$, Anna I. Kurbatova ${ }^{1}$, and Milana E. Kupriyanova ${ }^{2}$ \\ ${ }^{1}$ Peoples' Friendship University of Russia (RUDN University), Faculty of Ecology, 6 Miklukho- \\ Maklaya Street, Moscow, 117198, Russian Federation \\ ${ }^{2}$ Peoples' Friendship University of Russia (RUDN University), Faculty of Philology, 6 Miklukho- \\ Maklaya Street, Moscow, 117198, Russian Federation
}

\begin{abstract}
The effect of the curfew due to the pandemic of Covid-19 virus on the levels of air pollution in the historic center of Quito was evaluated with a focus on tropospheric ozone $\left(\mathrm{O}_{3}\right)$. During the curfew period the daily $\mathrm{O}_{3}$ mean concentration increased by $96 \%, 109 \%$ and $95 \%$ in comparison to the concentrations for the same period in the years 2017, 2018 and 2019. This increase is mainly explained by considerable reduction in NOx emissions, thus there was little titration of ozone accumulated in the city environment due to its shallow boundary layer by $\mathrm{NO}$, reaching its maximum concentration at midday. Among studied pollutants that influence $\mathrm{O}_{3}$ formation $\left(\mathrm{CO}, \mathrm{NO}_{2}, \mathrm{PM}_{2.5}\right)$ during the curfew the contaminant that showed the greatest reduction in the mean concentration compared to three previous years was $\mathrm{NO}_{2}$, followed by $\mathrm{CO}$ and $\mathrm{PM}_{2.5}$. The daily $\mathrm{O}_{3} 8$-hour mean concentrations during the curfew both on weekdays and weekends were lower than the limit values. These results are relevant for designing abatement policies of secondary pollutants such as $\mathrm{O}_{3}$ under strict measures of control of primary pollutant emissions.
\end{abstract}

\section{Introduction}

The dynamics of demographic growth that cities face represents a serious threat to the environment, as well as to the health and quality of life of its inhabitants. This growth generates new economic processes and is generally accompanied by an increase in industrial activities, number of vehicles and a greater consumption of fuel, generating greater emissions of air pollutants, which have caused 4.2 million premature deaths in 2016 [1].

According to the UN report (2015) 54\% of the world population lives in urban areas and it is expected that in 2050, it will reach 66\% [2]. According to the data from the last census carried out in Ecuador in 2010, 1'629,146 people lived in the urban area of Quito. In 2014, the population projections made by the city municipality determined that the population in the urban area of the city was 2414,585 . As per the municipality's estimates for the year 2022 , the population of the city of Quito will be almost 2.8 million inhabitants, of which $68 \%$ will reside in the urban area [3].

\footnotetext{
* Corresponding author: cristian salazarf@ hotmail.com
} 
In urban areas fine particulate matter $\left(\mathrm{PM}_{2.5}\right)$, nitrogen dioxide $\left(\mathrm{NO}_{2}\right)$ and tropospheric ozone $\left(\mathrm{O}_{3}\right)$ are among the most harmful air pollutants to human health. Long-term exposure to these pollutants is associated with cardiovascular and respiratory diseases [4-6].

At international level, the WHO air quality guidelines constitute the most consensual and scientifically supported analysis of the effects of pollution on health. However, this organization clearly establishes that each country must consider air quality standards that protect public health, according to social, technical and economic reality of each country (Table 1).

Table 1. Air quality standards (threshold limit values, TLV) established by the World Health Organization and the Ministry of the Environment in Ecuador [7].

\begin{tabular}{|c|c|c|c|}
\hline Pollutant & Average time & WHO & Ecuador \\
\hline \multirow{2}{*}{$\mathrm{NO}_{2}\left(\mathrm{ug} / \mathrm{m}^{3}\right)$} & 1-hour mean & 200 & 200 \\
\cline { 2 - 4 } & Annual mean & 40 & 40 \\
\hline \multirow{2}{*}{$\mathrm{CO}\left(\mathrm{mg} / \mathrm{m}^{3}\right)$} & 1-hour mean & 30 & 40 \\
\cline { 2 - 4 } & Daily 8-hour & 10 & 10 \\
\hline \multirow{2}{*}{$\mathrm{PM}_{2.5}\left(\mathrm{ug} / \mathrm{m}^{3}\right)$} & 24-hour mean & 25 & 50 \\
\cline { 2 - 4 } & Annual mean & 10 & 15 \\
\hline $\mathrm{O}_{3}\left(\mathrm{ug} / \mathrm{m}^{3}\right)$ & Daily 8-hour máximum & 100 & 120 \\
\hline
\end{tabular}

Mobile sources are major contributors to air pollution in the city of Quito, especially light and heavy vehicle emissions [8]. Table 2 presents an inventory of atmospheric emissions from vehicular traffic.

Table 2. Emissions from vehicular traffic in the city of Quito in 2012 [9].

\begin{tabular}{|c|c|c|}
\hline Pollutant & Total (ton/year) & Percentage (\%) \\
\hline NOx & $20,808.1$ & 14.9 \\
\hline CO & $10,2667.4$ & 73.3 \\
\hline COVNM & $13,185.6$ & 9.4 \\
\hline $\mathrm{PM}_{10}$ & $1,656.5$ & 1.2 \\
\hline $\mathrm{PM}_{2.5}$ & $1,211.2$ & 0.9 \\
\hline $\mathrm{SO}_{2}$ & 451.1 & 0.3 \\
\hline Total & $139,979.9$ & 100 \\
\hline
\end{tabular}

Quito is located at 2,850 meters above sea level, in a vast valley surrounded by mountains. These conditions give the city environment potential to accumulate pollutants due to the presence of a shallow boundary layer [10]. Air quality in Quito city, based on monitoring data, has remained relatively constant in recent years. In 2017, there were some marginal increases in the concentrations monitored compared to 2016. However, there have been substantial decreases in pollutants in a rural area of the city, the same ones that are due to the cessation of majority of the operations of a thermoelectric plant, which is located in this area. During 2017, the maximum 8-hour mean $\mathrm{O}_{3}$ concentration in the center of Quito was recorded in September $\left(95.7 \mathrm{ug} / \mathrm{m}^{3}\right)$, which was $4.3 \%$ less than the TLV. This concentration value according to the WHO does not represent a significant risk to public health, though some health effects may occur below this level. Exposure to this level of ozone is associated with an estimated 1-2\% increase in daily mortality [11].

Due to the poor-quality fuels used by the vehicle fleet, nine weeks of high pollution were recorded in 2018 [12]. In the period between 2017-2019, in the south of Quito the daily maximum 8-hour mean $\mathrm{O}_{3}$ concentration remained below the norm, although some days exceeded the maximum threshold limit value by $0.08 \%$ [13]. 
Vehicle emissions along with anthropogenic activities in the city, emit nitrogen oxides (NOx) and volatile organic compounds (VOCs) into the atmosphere, which with the help of sunlight generate tropospheric ozone $\left(\mathrm{O}_{3}\right)$. Since this is a secondary pollutant, its formation rate depends on the concentration of its precursors: nitrogen oxides $\left(\mathrm{NOx}=\mathrm{NO}+\mathrm{NO}_{2}\right)$ and volatile organic compounds (VOCs) emitted directly and mainly by exhaust from motorized vehicles.

The relation between $\mathrm{O}_{3}$, NOx and VOCs represent one of the main scientific challenges associated with air pollution in urban centers. It is generally known that it is affected by complex nonlinear photochemistry that expresses a certain sensitivity regime of the atmosphere itself. In some conditions, the $\mathrm{O}_{3}$ formation process is controlled almost entirely by NOx, being largely independent of the presence of VOCs, while in others the increase in ozone production is closely related to the increase in atmospheric VOC concentration, not increasing (but sometimes even decreasing) with the increase of nitrogen oxides [14-15].

The first reported case of Covid-19 in Ecuador was on February 29, 2020, when on February 14, a 71-year-old woman returned from Spain to the country. On March 13, 2020, the death of patient zero was notified. Cases from the end of the second month of the year increased in the national territory [16]. As a result, the following day a curfew from 2:00 p.m. to 5:00 a.m. from April to June, was established in the country. This restriction measure reduced all types of mobility and minimized activities in an unprecedented way, allowing an evaluation of the effect of anthropogenic activities on concentration levels of atmospheric pollutants under unique conditions.

As discussed by Zambrano et al. (2020), during the COVID-19 lockdown in Quito city the $\mathrm{NO}_{2}$ concentrations in March 2020, were on average 460\% lower than 2018 concentrations and $380 \%$ lower than those in 2019. The same happened with $\mathrm{PM}_{2.5}$. Compared with 2018 and 2019, the $\mathrm{PM}_{2.5}$ concentrations were 50\% and 60\% lower, respectively. Whereas, $\mathrm{O}_{3}$ concentrations in March 2020, on average increased up to $50 \%$ compared with 2018 and 100\% compared with 2019 [17]. Similar patterns were observed in Rio de Janeiro [18], Barcelona [19] Nice, Rome, Valencia, Turin and Wuhan [20]. In all these cities, the increase in $\mathrm{O}_{3}$ concentrations was related to the decrease in NOx concentrations.

The media and the international community, during the curfew, paid great attention to the decrease in $\mathrm{NO}_{2}$ concentrations, associating this fact with an improvement in air quality [21]. Both the NASA and the ESA noted that the concentration of $\mathrm{NO}_{2}$ in countries like Italy, Spain and the United States was reduced by up to $30 \%$ [22]. By contrast, less attention was paid to $\mathrm{O}_{3}$ without considering that a significant increase in $\mathrm{O}_{3}$ concentration represents a great danger to public health, so in this case it can be stated that air quality only partially improves.

This research aims to study the impact of the lockdown and curfew imposed due to the Covid-19 pandemic on the dynamics of air pollutants concentration such as $\mathrm{CO}, \mathrm{PM}_{2.5}, \mathrm{NO}_{2}$ and $\mathrm{O}_{3}$ in particular, in one of the most popular touristic areas of the Quito city with the highest traffic congestion.

\section{Method}

The historical center is located in the south center of the city of Quito, covering an area of 375.2 hectares and is considered as one of the most important and best preserved historical complexes in Latin America. The population of the historic center in 2010, was 49,384 inhabitants according to the last national population and housing census, presenting a high population density rate of $10,832.2$ inhabitants $/ \mathrm{km}^{2}$ [19].

The air quality monitoring network of the Quito city is equipped with eight automatic stations to measure in real time concentrations of $\mathrm{SO}_{2}, \mathrm{CO}, \mathrm{NO}_{2}, \mathrm{O}_{3}, \mathrm{PM}_{10}$ and $\mathrm{PM}_{2.5}$. The hourly concentrations of these pollutants are available on the official website of the city municipality. 
The location of the automatic air quality monitoring stations meets the recommendations of the United States Environmental Protection Agency (US-EPA) (EPA. 40CFR58, Appendix E) and the World Meteorological Organization (WMO, No. 8) [11].

The automatic station measuring air pollution levels in the historic city center called "Centro" is located at coordinates $78^{\circ} 30^{\prime} 36^{\prime \prime} \mathrm{W}, 0^{\circ} 13^{\prime} 12$ " S, at a height of 2,820 meters above sea level (Fig. 1).

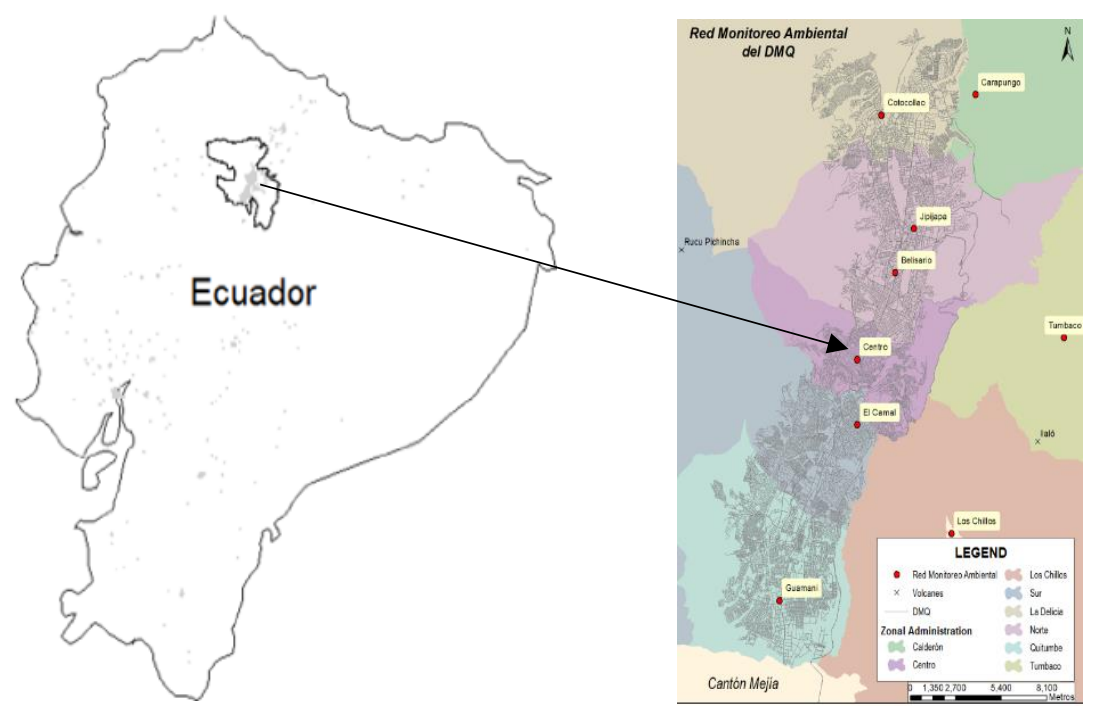

Fig. 1. Location of the automatic air quality monitoring stations. The Centro automatic station is located in the historic center of the Quito city.

To quantify the effect of the curfew established in the city on air pollutant levels, in addition to $\mathrm{O}_{3}$, the behavior of its precursors was studied. Hourly concentrations of $\mathrm{CO}, \mathrm{NO}_{2}$, $\mathrm{PM}_{2.5}$ and $\mathrm{O}_{3}$ provided by the Centro automatic station were processed from April to June for the years 2017, 2018, 2019 and 2020. Table 3 indicates gas and particle analyzers used in the Centro monitoring station and the principle of operation.

Table 3. Pollutants measuring equipment in the Centro monitoring station [11].

\begin{tabular}{|c|c|c|}
\hline Pollutant & Measuring equipment & Principle of operation \\
\hline $\mathrm{CO}$ & Thermo 48C / 48i & Non-dispersive infrared \\
\hline $\mathrm{NOx}$ & Thermo 42C / 42i & Chemiluminescence \\
\hline $\mathrm{PM}_{2.5}$ & Thermo Andersen / FH62C14 & Beta ray attenuation \\
\hline $\mathrm{O}_{3}$ & Thermo 49C / 49i & Ultraviolet absorption \\
\hline
\end{tabular}

To detect and estimate the changes of air pollution levels during the curfew, the variations in the daily mean concentrations (expressed in\%) were calculated, taking as a reference the concentrations of the equivalent period in the years 2017, 2018 and 2019. In order to investigate timing relationships between levels of $\mathrm{NOx}$ and $\mathrm{O}_{3}$, diurnal patterns of $\mathrm{NO}_{2}$ and $\mathrm{O}_{3}$ concentrations on weekdays and weekends before the curfew (January 1 to March 31) and during the curfew (April 1 to June 30) were studied.

To estimate the difference between a long reduction in activities compared to the typical reduction in activities that occurs at weekends (weekend effect), the variations in $\mathrm{O}_{3} 8$-h mean concentrations on weekends with respect to weekdays during the curfew were compared. The same comparison was done for the years 2017, 2018, 2019. 
In addition, the variations of the $\mathrm{O}_{3} 8$-h mean concentrations during the weekdays in the curfew period with respect to weekdays of the same period in the previous three years as well as during weekends in the curfew with respect to the weekends in the years 2017, 2018 and 2019 were compared. $\mathrm{O}_{3} 8$-h concentrations were acquired as the mean of the hourly concentrations between 9 a.m. to 4 p.m., as during this period the $\mathrm{O}_{3}$ concentrations are higher in the Quito city.

\section{Results and discussion}

By averaging the mean daily concentrations of $\mathrm{CO}, \mathrm{PM}_{2.5}, \mathrm{NO}_{2}$ and $\mathrm{O}_{3}$ during the period April-June for the years 2017 to 2020 respectively, a significant decrease in the concentration of all pollutants except $\mathrm{O}_{3}$ is observed in 2020 (Fig. 2).
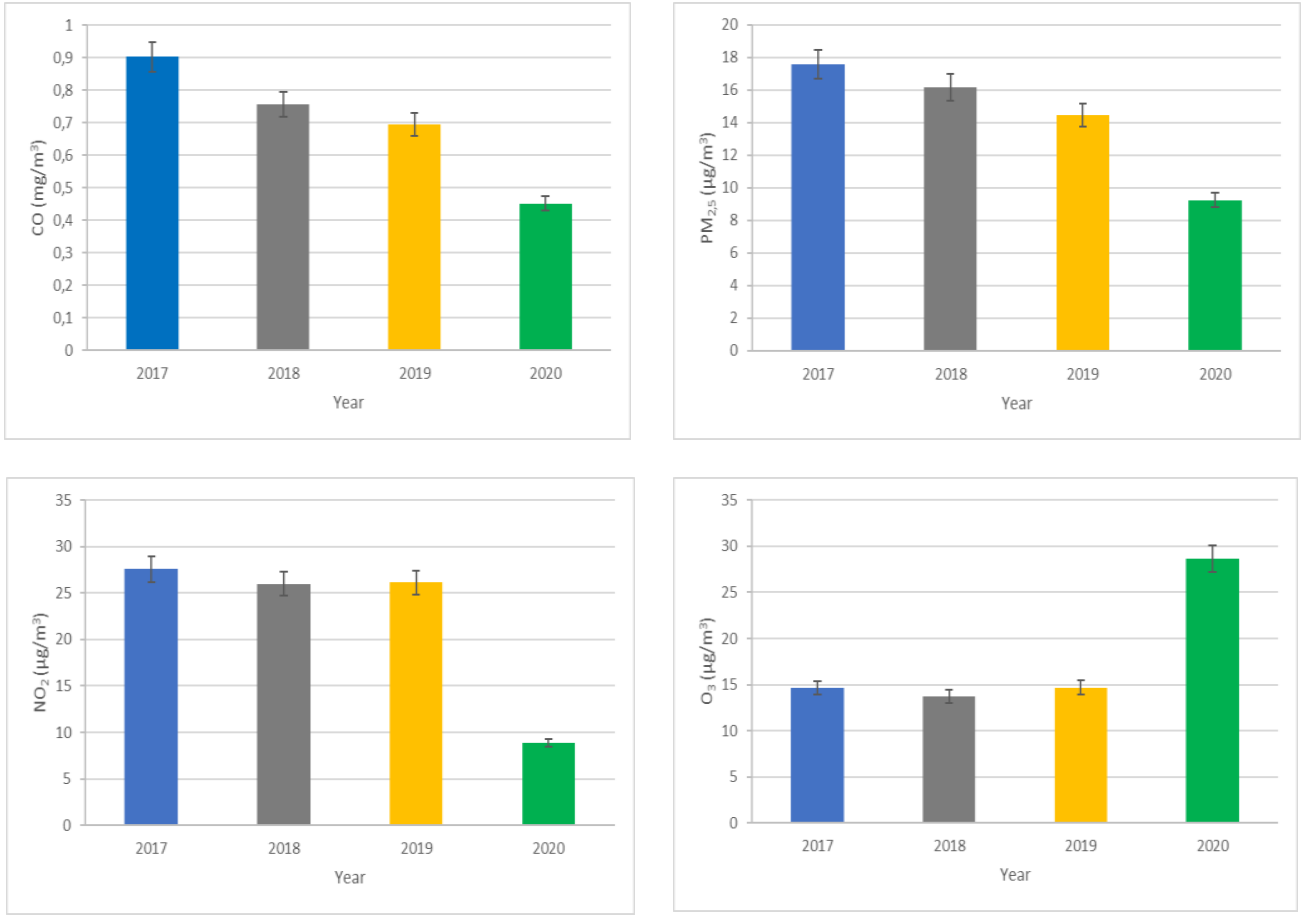

Fig. 2. Daily mean concentrations of $\mathrm{CO}, \mathrm{PM}_{2.5}, \mathrm{NO}_{2}$ and $\mathrm{O}_{3}$ from April to June in the years 2017, 2018, 2019 and 2020.

According to Fig. 2, from April to June in the years 2017, 2018, 2019 and 2020 the mean values of $\mathrm{CO}$ were $0.9 \mathrm{mg} / \mathrm{m}^{3}, 0.7 \mathrm{mg} / \mathrm{m}^{3}, 0.6 \mathrm{mg} / \mathrm{m}^{3}$ and $0.4 \mathrm{mg} / \mathrm{m}^{3}$ respectively, of $\mathrm{PM}_{2.5}$ were $17.5 \mu \mathrm{g} / \mathrm{m}^{3}, 16.1 \mu \mathrm{g} / \mathrm{m}^{3}, 14.4 \mu \mathrm{g} / \mathrm{m}^{3}$ and $9.2 \mu \mathrm{g} / \mathrm{m}^{3}$ respectively, of $\mathrm{NO}_{2}$ were 27.5 $\mu \mathrm{g} / \mathrm{m}^{3}, 25.9 \mu \mathrm{g} / \mathrm{m}^{3}, 26.1 \mu \mathrm{g} / \mathrm{m}^{3}$ and $8.8 \mu \mathrm{g} / \mathrm{m}^{3}$ respectively, and of $\mathrm{O}_{3}$ were $14.6 \mu \mathrm{g} / \mathrm{m}^{3}, 13.7$ $\mu \mathrm{g} / \mathrm{m}^{3}, 14.7$ and $28.6 \mu \mathrm{g} / \mathrm{m}^{3}$ respectively.

Compared to the mean concentrations in the years 2017, 2018 and 2019 during the months of April to June in 2020, there was a decrease in the concentrations of CO by $55 \%, 42 \%$, $33 \%$, of $\mathrm{PM}_{2.5}$ by $47 \%, 42 \%, 36 \%$ and of $\mathrm{NO}_{2}$ by $68 \%, 65 \%, 66 \%$, respectively. According to these values, due to the curfew, the most significant reduction was in $\mathrm{NO}_{2}$ mean concentration compared to the other pollutants studied. The main source of $\mathrm{NO}_{\mathrm{x}}$ emission is the combustion of fossil fuels from both mobile and stationary sources. In the case of the center of Quito, being one of the most popular touristic places in the city, the high vehicular flow makes cars its main source of emission. Due to the curfew, a vehicle restriction was 
implemented, which reduced traffic congestion, so lower levels of NO emissions and other pollutants were registered.

Regarding $\mathrm{O}_{3}$, there is an increase in concentration during the curfew compared to the years 2017,2018 and 2019 by $96 \%, 109 \%$ and $95 \%$ respectively. Generally, in areas with high vehicular traffic, $\mathrm{O}_{3}$ formation depends on a low VOC/NOx ratio (less than 8) [23]. In the case of Quito, a study carried out during 2014, determined that ozone formation in the city of Quito is generally limited by VOCs [10], so the ozone concentration depends mainly on the amount of VOC, that is, the ozone concentration increases with increasing VOC and decreases with increasing NOx or vice versa.
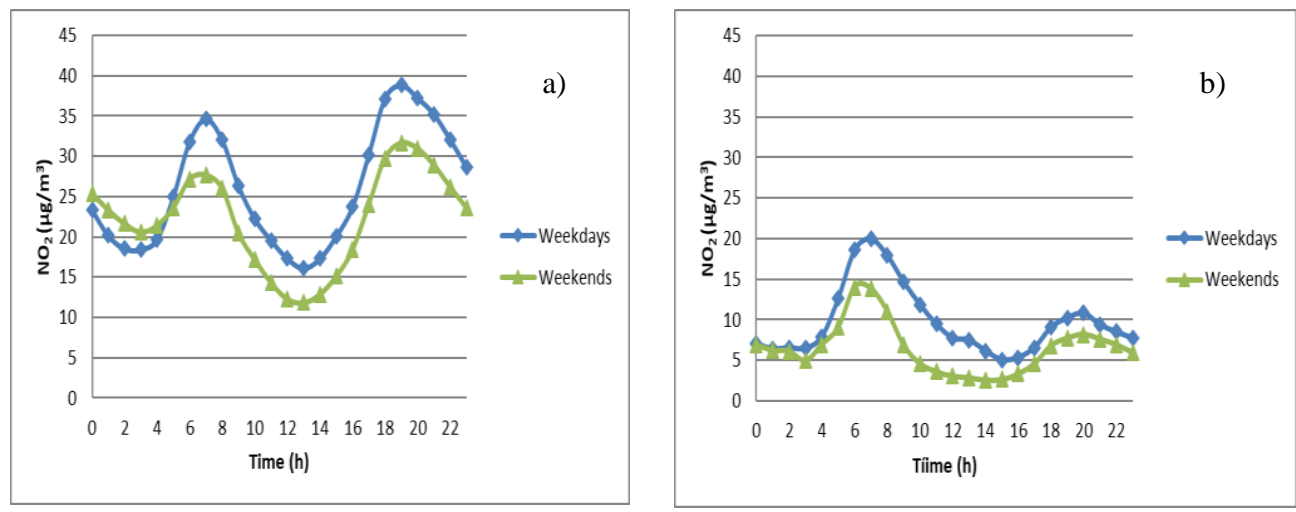

Fig. 3. Diurnal patterns of $\mathrm{NO}_{2}$ concentrations a) before the curfew (January 1 to March 31); b) during the curfew (April 1 to June 30).

As per Fig. $3 \mathrm{a}$ and $3 \mathrm{~b}$ the $\mathrm{NO}_{2}$ concentration hourly profiles before and during the curfew show 2 maximum concentration peaks, one of them at 7 a.m. and another one at 8 p.m. both on weekdays and weekends. While the minimum concentration both on weekdays and weekends was recorded at 3 p.m. before and during the curfew.

During the curfew, the $\mathrm{NO}_{2}$ mean concentration at 7 a.m. both on weekdays $\left(20 \mu \mathrm{g} / \mathrm{m}^{3}\right)$ and weekends $\left(13.8 \mu \mathrm{g} / \mathrm{m}^{3}\right)$ was $42 \%$ and $50 \%$ lower compared to weekdays $\left(34.5 \mu \mathrm{g} / \mathrm{m}^{3}\right)$ and weekends $\left(27.6 \mu \mathrm{g} / \mathrm{m}^{3}\right)$ before curfew, respectively. This concentration peak recorded at 7 a.m., is possibly the result of atmospheric temperature inversions, this phenomenon occurs in the early hours of the morning, where the atmosphere is more stable, preventing the vertical dispersion of pollutants accumulated during the previous night and early morning.

The $\mathrm{NO}_{2}$ mean concentration at $8 \mathrm{p} . \mathrm{m}$. on weekdays during the curfew $\left(10.8 \mu \mathrm{g} / \mathrm{m}^{3}\right)$ was $70 \%$ lower in comparison to concentration on weekdays before the curfew $\left(37.2 \mu \mathrm{g} / \mathrm{m}^{3}\right)$, while the concentration on weekends during the curfew $\left(8.2 \mu \mathrm{g} / \mathrm{m}^{3}\right)$ was $73 \%$ lower in comparison to weekends before the curfew $\left(30.9 \mu \mathrm{g} / \mathrm{m}^{3}\right)$. This concentration peak at night corresponds to peak traffic levels. 

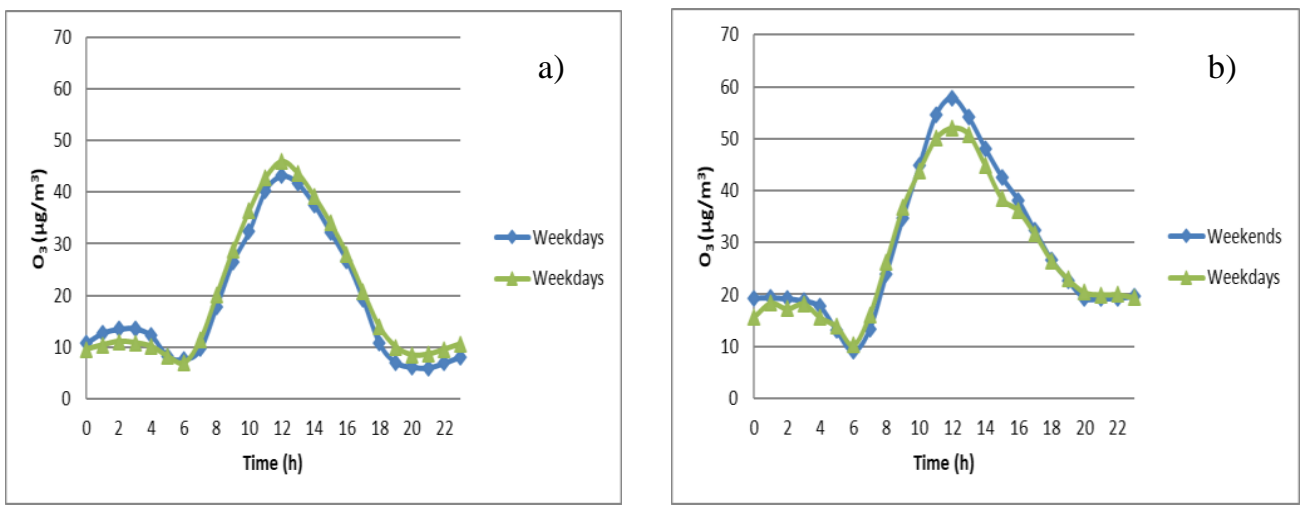

Fig. 4. Diurnal patterns of $\mathrm{O}_{3}$ concentrations a) before the curfew (January 1 to March 31 ); b) during the curfew (April 1 to June 30).

Diurnal patterns of hourly $\mathrm{O}_{3}$ mean concentrations before and during the curfew both on weekdays and weekends show that the highest concentration was recorded at midday (Fig. $4 \mathrm{a}$ and $4 \mathrm{~b}$ ). This concentration peak is associated with the fact that in the city of Quito maximum solar radiation is recorded at 12 p.m., so a high atmospheric temperature favorably affected the kinetics of the ozone formation reaction.

Before the curfew at midday the $\mathrm{O}_{3}$ concentration on weekends $\left(46 \mu \mathrm{g} / \mathrm{m}^{3}\right)$ was $7 \%$ higher than the concentration on weekdays $\left(43.1 \mu \mathrm{g} / \mathrm{m}^{3}\right)$, while in the period of the curfew the $\mathrm{O}_{3}$ concentration on weekends at midday $\left(52.1 \mu \mathrm{g} / \mathrm{m}^{3}\right)$ was $10 \%$ lower than the concentration on weekdays $\left(57.8 \mu \mathrm{g} / \mathrm{m}^{3}\right)$.

In the curfew period, the $\mathrm{O}_{3}$ mean concentration at 12 p.m. on weekdays was $34 \%$ and weekends $13 \%$ higher in comparison with the weekdays and weekends before the curfew. The increase in $\mathrm{O}_{3}$ concentration during the curfew could be related to the fact that in the morning there was a low titration of $\mathrm{O}_{3}$ by NO, due to the decrease in NOx emissions, so large amount of $\mathrm{O}_{3}$ did not react and remained in the atmosphere, reaching its maximum concentration at midday.

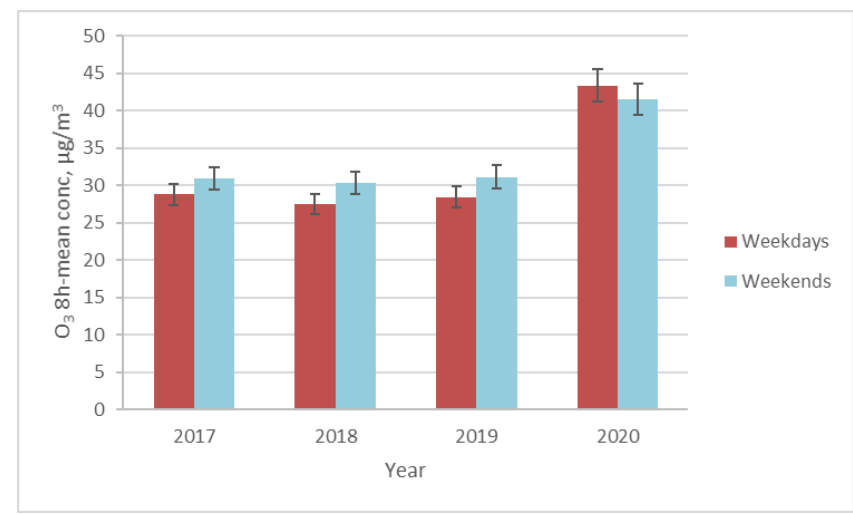

Fig. 5. $\mathrm{O}_{3}$ 8-h mean concentrations on weekdays and weekends from April to June in the years 2017, 2018,2019 and 2020.

According to Fig. 5 during the period from April to June in the years 2017, 2018 and 2019 the highest $\mathrm{O}_{3} 8$-h mean concentrations were recorded on weekends compared to weekdays, evidencing the existence of the ozone weekend effect. These results are corroborated by a study carried out on the weekend effect in the city of Quito in 2012 [23], which indicates the presence of WE in the historic center of Quito. 
The percentage of variation of the $\mathrm{O}_{3} 8$-h mean concentration during the weekends compared to weekdays in 2017 was 7\%, in 2018 - 10\% and in 2019 - 9\% respectively. In the period from April to June of the year 2020, the ozone weekend effect was not identified, since the $\mathrm{O}_{3} 8$-h mean concentration during weekend $\left(41.5 \mu \mathrm{g} / \mathrm{m}^{3}\right)$ was lower compared to that of weekdays $\left(43.3 \mu \mathrm{g} / \mathrm{m}^{3}\right)$ by $4 \%$.

The $\mathrm{O}_{3} 8$-h mean concentration during the weekdays from April to June in 2020 (43.3 $\mu \mathrm{g} / \mathrm{m}^{3}$ ) was $50 \%, 57 \%$ and $52 \%$ higher compared to the weekdays of the equivalent period in the years $2017\left(28.7 \mu \mathrm{g} / \mathrm{m}^{3}\right), 2018\left(27.5 \mu \mathrm{g} / \mathrm{m}^{3}\right)$ and $2019\left(28.4 \mu \mathrm{g} / \mathrm{m}^{3}\right)$ and during the weekends from April to June in $2020\left(41.5 \mu \mathrm{g} / \mathrm{m}^{3}\right)$ was $34 \%, 36 \%$ and $33 \%$ higher compared to the weekends of the same period in the years $2017\left(30.9 \mu \mathrm{g} / \mathrm{m}^{3}\right), 2018\left(30.3 \mu \mathrm{g} / \mathrm{m}^{3}\right)$ and $2019\left(31.1 \mu \mathrm{g} / \mathrm{m}^{3}\right)$. According to these results, the most significant variation in $\mathrm{O}_{3}$ production during the curfew in comparison to the same period in three previous years was on weekdays.

During the curfew, the $\mathrm{O}_{3} 8$-h mean concentration on weekdays $\left(43.3 \mu \mathrm{g} / \mathrm{m}^{3}\right)$ was $56 \%$ lower than the threshold limit value established by Ecuadorian standard, while the $\mathrm{O}_{3} 8-\mathrm{h}$ mean concentration on weekends $\left(41.5 \mu \mathrm{g} / \mathrm{m}^{3}\right)$ was $58 \%$ lower than the TLV.

The main limitation of this study is that meteorological variables are not taken into account when the concentrations of pollutants during the curfew period and the concentrations of previous years are compared. Weather can affect pollutant concentrations, including the formation of secondary pollutants. In addition, due to cold weather higher emissions of fuel burn can be registered [24]. However, the changes in concentrations between the years were substantially large, so these variations can be mainly attributed to the quarantine policies established during the curfew period.

\section{Conclusion}

The curfew, implemented in the city of Quito in the context of COVID-19 pandemic, led to a vehicle restriction, closure of businesses and industrial activities. This caused a decrease in $\mathrm{NO}$ emissions of pollutant concentrations, that reduced $\mathrm{NO}_{2}$ concentrations. During the curfew the daily $\mathrm{NO}_{2}$ mean concentrations decreased by $67 \%, 65 \%, 66 \%$, CO by $50 \%, 40$, $35 \%$ and $\mathrm{PM}_{2.5}$ by $47 \%, 42 \%, 36 \%$ with respect to the same period in the years 2017,2018 and 2019 respectively. The increase in the daily $\mathrm{O}_{3}$ mean concentration compared to the mean concentration of the previous 3 years was by $95 \%, 108 \%$ and $94 \%$ respectively. This increase is the result of low concentrations of NO due to the reduction of NOx emissions, so that a large amount of the accumulated ozone (due to atmospheric temperature inversions) didn't react and remained in the air. The increase in the $\mathrm{O}_{3}$ concentration level can be compared to the causes of the weekend effect under limited VOC conditions. The analysis showed that the most significant variation in $\mathrm{O}_{3}$ production during the curfew in comparison to the same period in three previous years was on weekdays. Both on weekends and weekdays the daily $\mathrm{O}_{3}$ 8-h mean concentrations were lower than the TLV established by Ecuadorian air quality standard.

\section{Acknowledgements}

The publication has been prepared with the support of the "RUDN University" Program 5100.

\section{References}

1. World Health Organization, Global health statistics 2015 (WHO, Luxembourg, 2015) 
2. P. Bocquier, Demog. Res. 12, 197 (2005)

3. Secretaría de Territorio, Hábitat y Vivienda, Población e indicadores de la Administración Zonal Manuela Sáenz según parroquias (Quito, Ecuador, 2010)

4. M. Telles, I. Romieu, M. Polo, S. Ruiz, F. Meneses, M. Hernández, Salud pública Méx 39, 513 (1997)

5. A. Kurbatova, K. Mikhaylichenko, A. Dorontsova, IOP Conf. Ser. Earth Environ. Sci. 272, 022107 (2019)

6. W. Gauderman, R. Urman, E. Avol, K. Berhane, R. McConnel, E. Rappaport, R. Chang, F. Lurmann, F. Gilliland, N. Engl. J. Med. 372, 905 (2015)

7. J. Manosalvas, Análisis temporal multivariante de la contaminación atmosférica dentro del distrito de metropolitano de Quito (Diss. Madrid, España, 2017)

8. V. Brachtl, L. Durant, P. Perez, J. Oviedo, F. Sempertegui, N. Naumova, K. Griffiths, Environ. Pollut. 157, 528 (2009)

9. D. Vega , L. Ocaña, R. Parra, ACI 7, (2015)

10. M. Cazorla, Atmos. Pollut. Res. 7, 66 (2016)

11. Secretaría de Ambiente de Quito, Informe de la calidad del aire-2017 (Quito, Ecuador, 2018)

12. J. Machado, El aire de Quito supera los límites permitidos de contaminación (Primicias, Quito, Ecuador, 2020)

13. C. Salazar, F. Mullo, E3S Web Conf. 169, 01067 (2020)

14. X. Jin, A. Fiore, L. Murray, L. Valin, L. Lamsal, B. Duncan, K. Folkert, I. De Smedt, G. Gonzalez, K. Chance, G. Tonnesen, J. Geophys. Res. Atmos. 122, 10 (2017)

15. S. Sanford, Atmos. Environ. 33, 1821 (1999)

16. A. Haro, Caracterización epidemiológica de Covid-19 en Ecuador, IAJMH 3, 1 (2020)

17. M. Zambrano, M. Ruano, Air Qual. Atmos. Hlth., 1 (2020)

18. B. Siciliano, G. Dantas, C. Da Silva, G. Arbilla, Sci. Total Environ. 737, 139765 (2020)

19. A. Tobias, C. Carnerero, C. Reche, J. Massagué, M. Via, M. Minguillón, A. Alastuey, X. Querol, Sci. Total Environ., 726, 138540 (2020)

20. P. Sicard, A. De Marco, E. Agathokleous, Z. Feng, X. Xu, E. Paoletti. J. Diéguez, V. Calatayud, Sci. Total Environ. 735, 139542 (2020)

21. Q. Wang, M. Su, Sci. Total Environ. 728, 138915 (2020)

22. S. Muhammad, X. Long, M. Salman, Sci. Total Environ. 728, 138820

23. E. Franco, Identificación del efecto fin de semana en la calidad de aire de QuitoEcuador, BS tesis (Quito, Ecuador, 2015)

24. J. Berman, K. Ebisu, Sci. Total Environ. 739, 139864 (2020) 